\title{
Effect of Some Non-genetic Factors and Fec-B Gene Introgression on Performance Traits of Kashmir Merino Sheep
}

\author{
Mubashir Ali Rather ${ }^{1 *}$, Suhail Magray ${ }^{2}$, Showkat Ahamad Ahanger ${ }^{1}$, Mohmmad Ashraf \\ Baba $^{1}$, M. Maroof Shah ${ }^{2}$, Tenveer Ahmad Rather ${ }^{2}$, Younis Farooq ${ }^{1}$ and Qayim Abbas ${ }^{1}$ \\ ${ }^{1}$ Department of Sheep Husbandry-Kashmir, J\&K, India \\ ${ }^{2}$ Diseases Investigation Laboratory-Kashmir, $J \& K$, India \\ *Corresponding author
}

\section{Keywords}

Fec-B gene introgression, Kashmir Merino, Year, Sex

Article Info

Accepted: 04 July 2019 Available Online: 10 August 2019

\section{A B S T R A C T}

The data pertaining to 623 purebred and $202 \mathrm{Fec}-\mathrm{B}$ gene introgressed Kashmir Merino lambs born to 25 and 11 sires, respectively were analyzed with the Mixed Model Least Squares and Maximum Likelihood algorithms, PC-2 version computer programme (Harvey. 1990) to assess the effect of Fec-B gene introgression and some non-genetic factors on performance traits of Kashmir Merino sheep. The overall least-squares means for birth weight (BW), weaning weight (WW), six months body weight (W6), yearling body weight (W12), adult body weight (W18), Average greasy fleece weight (AGW), fibre diameter (FD), staple length (SL), Crimps/ cm (CPC), Medullation (ML) and litter size (LS) were $3.27 \pm 0.03(\mathrm{Kg}), 11.38 \pm 0.16(\mathrm{Kg}), 16.30 \pm 0.45(\mathrm{Kg})$, $19.54 \pm 0.23(\mathrm{Kg}), 24.23 \pm 0.27(\mathrm{Kg}), 32.43 \pm 0.41(\mathrm{Kg}), 1.75 \pm 0.03(\mathrm{Kg}), 20.99 \pm 0.10(\mu)$, $3.43 \pm 0.10(\mathrm{~cm}), 4.84 \pm 0.0 .20(\mathrm{No} / \mathrm{cm}) 3.26 \pm 0.37(\%)$ and $1.20 \pm 0.22$, respectively. Purebred Kashmir Merino performed better than Fec-B transgressed. However, the difference was significant for BW, AGW, CWY, FD and ML. The effect of year of birth was significant on all traits except W18. However, the effect of age of dam was non-significant on all traits. The effect of sex was significant on BW, W12, FD and CPC. The birth weight and wool traits were significantly affected by Fec-B introgression.

\section{Introduction}

Kashmir Merino is a predominant sheep breed of state of Jammu and Kashmir with a population more than 11.15 lakhs (Anonymous, 2018). The breed is known for production of superior quality fine wool, fast growth rate and adaptation to wide range of environmental conditions. But due to the easy availability of fine \& good quality synthetic fibers, wool has lost its market value. However, due to mutton preference in the country there is huge demand for mutton traits. The mutton preference in country has resulted in huge gap between supply and demand. This gap can be bridged by augmenting the productivity of the available sheep genetic resources simultaneously conserving the improvement achieved in wool traits. One method to bridge the gap was 
increasing litter size per ewe. Therefore, FecB gene was introgressed into Kashmir Merino sheep to increase litter size. Therefore, present investigation was undertaken to study effects of the Fec-B intragression on some performance traits.

\section{Materials and Methods}

The data spread over four years (2014-2017), pertaining to 623 purebred Kashmir Merino and 202 Fec-B gene introgressed lambs born to 25 and 11 sires, respectively were collected from flock books, body weight and wool record registers maintained at Government Sheep Breeding Farm Gobal, Kashmir, India for the present investigation. The farm is located at $34^{\circ} 16^{\prime}$ latitude $\mathrm{N}$ and $53^{\circ} 49^{\prime}$ longitude E, about 50 kilometers from Srinagar. The sheep are stall-fed during winter for four and half months from fifteen November to first April only. The fodder is fed to animals @ $1.5 \mathrm{~kg}, 1.6 \mathrm{~kg}$ and $1.6 \mathrm{~kg}$ per day per adult ewe, ram and hogget, respectively. The concentrate ration is fed @ 600gms/day/adult male and @ 500gms /day/ewe and @ 300gms /sheep having age under one year. The sheep are fed pelleted feed, maize, wheat bran, oil cakes, jaggery and mineral mixture. Sheep are not provided any feed and fodder from first April to $15^{\text {th }}$ November except during draught periods. However, the common salt @ $10 \mathrm{gms} / \mathrm{head} /$ week is given to these animals. Ewes were mated in the late summer and early autumn after flushing and screening for Brucellosis. The ewes having body weight less than $30 \mathrm{~kg}$ were abstained from breeding. The ewes rams were selected on the basis of their body weight, wool yield and quality. However, due care was taken to avoid close inbreeding. Paint was applied on the brisket region of selected rams and put into the pens with allotted group of ewes for day and night. Tupping was recorded in the morning and evening. The lambing commenced in January and terminated at the end of March. Lambs were weaned at an age of 4-5 months. The animals were machine shorn twice a year. FecB gene introgression project was started at SBF Goabal in 2011 on experimental basis in collaboration with SKUAST-K to introgress Fec-B gene in Kashmir Merino to boost the production potential of sheep industry in the state. Subsequently NARI Swarna Merino Rams were imported from SKUAST $-\mathrm{K}$ and were bred with non-carrier Kashmir Merino ewes. The F1 so obtained was back crossed with Kashmir Merino Rams to recover the superior recipient genome. The data was suitably classified to study the major effects. The data was analyzed by Least Squares and Maximum Likelihood Computer Program, PC-2 version (Harvey 1990) to assess the random effect of sire and fixed effects of year, gender, Fec-B intrograssion and age of dame on various production traits. The model used for the present investigation was, $\mathrm{Y}_{\mathrm{ijk} k \mathrm{mn}}=\mu$ $+R_{i}+Y_{j}+A_{k}+G_{1}+B_{m}+e_{i j k l m n}$. Where $Y_{i j k l m n}=$ Observation of $\mathrm{n}^{\text {th }}$ lamb of $\mathrm{m}^{\text {th }}$ genotype, having $1^{\text {th }}$ gender, born to dame in $\mathrm{k}^{\text {th }}$ age group in $j^{\text {th }}$ year, and born to $i^{\text {th }}$ sire. Fixed effects evaluated for the production traits were breed, (Kashmir Merino, fec-B), gender of lamb (male, female), age of Dame $(<36,36-$ $48,48-60,60-72$ and $>72$ months), year of lambing (2014, 2015, 2016 and 2017). The statistical significance of various fixed effects in the least squares model was determined by ' $F$ ' test. For significant effects, the differences between pairs of levels of effects of period were tested by Duncan's multiple range test (DMRT) as modified by Kramer 1957.

\section{Results and Discussion}

The overall least-squares means for birth weight (BW), weaning weight (WW), six months body weight (W6), yearling body weight (W12), adult body weight (W18), Average greasy fleece weight $(\mathrm{AGW})$, fibre diameter (FD), staple length (SL), Crimps/ cm 
(CPC), Modulations (ML) and litter size (LS) were $3.27 \pm 0.03 \quad(\mathrm{Kg}), \quad 11.38 \pm 0.16 \quad(\mathrm{Kg})$, $16.30 \pm 0.45 \quad(\mathrm{Kg}), \quad 19.54 \pm 0.23 \quad(\mathrm{Kg})$, $24.23 \pm 0.27(\mathrm{Kg}), 32.43 \pm 0.41(\mathrm{Kg}), 1.75 \pm 0.03$ $(\mathrm{Kg}), \quad 20.99 \pm 0.10 \quad(\mu), \quad 3.43 \pm 0.10(\mathrm{~cm})$, $4.84 \pm 0.0 .20 \quad(\mathrm{No} / \mathrm{cm}) \quad 3.26 \pm 0.37 \quad(\%)$ and $1.20 \pm 0.22$, respectively (Table 1 ). Das et al., (2014) in Kashmir Merino reported a similar value for FD and higher value for SL. More or less similar values of LSM's for SL and ML were reported by Dixit et al., (2009) in $3 / 4^{\text {th }}$ Bred Bharat Merino Sheep. Dey (2004) in Munjal sheep and Lalit et al., (2017) in Harnali reported more or less similar estimates for BW, WW, W6, AGW and SL. However, Kannojia el al. (2016) in Marwari sheep and Yadav et al., (2018) In Munjal sheep reported higher values for BW, WW, SMW, YW and AGW. Dixit et al., (2009) in $3 / 4^{\text {th }}$ Bred Bharat Merino Sheep observed a lower estimate for FD.

The effect of Fec-B gene introgression: The lambs born to sire introgressed with Fec-B gene were comparatively having lower body weights at all ages. However, significant differences were observed between birth weights only. The lower birth weight for lambs born to Fec B group may be due to increased number of multiple born lambs having low birth weight. Gootwine et al., (2006) in dairy Assaf breed also reported significantly lower birth weight for lambs born to sires and dams carrying Fec-gene than those born to not carrying Fec-b gene. All wool traits except staple length were significantly affected by Fec-B intrograssion Table 1. The effect on wool traits may be due to difference in wool production of NARI Swarna Merino Rams (Rams used for Fec-B introgression) and Kashmir Merino sheep. The wool production traits of progeny born to Fec-B intragressed sires can be improved by back crossing with Kashmir Merino rams. Ponzoni et al., (1985a and b), Meyer et al., (1994) and Walkden-Brown et al., (2007) reported non- significant differences between lambs carrying Fec-B and lambs not carrying Fec-B gene. The litter size was significantly higher in Fec-B gene treated animals by 0.32 numbers. Nimbkar et al., (2007), Kumar et al., (2008), Chu et al., (2007) and Guan et al., (2007) have also reported significant increase in litter size due to Fec-B gene introgression in different sheep breeds.

The effects of year of birth significantly influenced the BW, W6, 9-MWT, 12-MWT, 18-MWT, GFW, FD, SL, no of crimps/cm and ML \%. The effect of sex was highly $(p<0.01)$ significant on BW, 9-MWT, 12 MWT, 18MWT, FD and SL. The effect of sex was highly $(\mathrm{p}<0.01)$ significant on BW, 9-MWT, 12 MWT, 18- MWT, FD and SL. The effect of age of dame was significant on BW, 12MWT, 18MWT, FD, SL and crimps. The differences in performance of sheep between two sexes and across years is reflection of hormonal differences among two sexes and differences in external environmental conditions between years.

These results are similar to the findings of earlier researcher. Various researchers also reported significant effect of year of birth and sex of lamb on body weight traits (Vivekanand et al., 2014 in Magra, Zaffer et $a l$., 2015 in Rambouillet, Dorper and their crosses, Ashraf. 2016 in Corriedale, Tohidi et al., 2017 in Iran Black sheep, Lalit et al., 2017 in Harnali sheep and Yadav et al., 2018 in Munjal), and wool traits in sheep (Khan et al., 2013 and Mahajan et al., 2018 in Rambouillet sheep and Lalit et al., 2017 in Harnali sheep). Male lambs were heavier than female for the body weight at all stages. Dey (2004) in Munjal sheep, Lalit et al., (2017) in Harnali, Das et al., (2014) in Kashmir Merino, Kannojia et al., (2016) in Marwari sheep and Yadav et al., (2018) In Munjal sheep also observed that male lambs were heavier than female lambs at different ages. 
Table.1 Least squares means along with standard errors for body weight and wool traits

\begin{tabular}{|c|c|c|c|c|c|c|c|}
\hline & & \multicolumn{6}{|c|}{ Growth traits } \\
\hline $\begin{array}{l}\text { Non-genetic } \\
\text { factor }\end{array}$ & $\mathbf{N}$ & BW & WW & W6 & W9 & W12 & W18 \\
\hline Overall & 827 & $3.27 \pm 0.03$ & $11.38 \pm 0.16$ & $16.30 \pm 0.45$ & $19.54 \pm 0.23$ & $24.23 \pm 0.27$ & $32.43 \pm 0.41$ \\
\hline Fec- introgression & & $(\mathrm{p}=.02)^{*}$ & $\left(\mathrm{p}=105_{-}^{\mathrm{NS}}\right.$ & $\mathrm{p}=(0.64)^{\mathrm{NS}}$ & $\mathrm{p}=(742)^{\mathrm{NS}}$ & $\mathrm{p}=(0.062)^{\mathrm{NS}}$ & $\mathrm{p}=(0.404)^{\mathrm{NS}}$ \\
\hline PKM & 625 & $3.45 \pm 0.04^{\mathrm{a}}$ & $11.42 \pm 0.19$ & $17.78 \pm 0.46$ & $19.75 \pm 0.28$ & $24.07 \pm 0.32$ & $32.47 \pm 0.49$ \\
\hline Fec-b KM & 202 & $3.10 \pm 0.05^{b}$ & $11.35 \pm 0.22$ & $16.54 \pm 0.55$ & $19.24 \pm 0.45$ & $23.38 \pm 0.47$ & $32.36 \pm 0.69$ \\
\hline year & & $(\mathrm{p}=0.0001)^{* *}$ & $(\mathrm{p}=0.0001)^{* *}$ & $(\mathrm{p}=0.0001)^{* *}$ & $(\mathrm{p}=0.0001)^{* *}$ & $(\mathrm{p}=0.0001)^{* *}$ & $(\mathrm{p}=0.140)^{* *}$ \\
\hline 2014 & 263 & $3.13 \pm 0.05$ & $10.13 \pm 0.22$ & $13.55 \pm 0.56^{\mathrm{a}}$ & $18-41 \pm 0.44^{\mathrm{a}}$ & $21.68 \pm 0.64$ & $31.654 \pm 0.89$ \\
\hline 2015 & 284 & $3.15 \pm 0.04$ & $11.57 \pm 0.23$ & $16.37 \pm 0.56^{b}$ & $17.71 \pm 0.48^{\mathrm{a}}$ & $21.16 \pm 0.51$ & $32.129 \pm 0.69$ \\
\hline 2016 & 125 & $3.35 \pm 0.06$ & $11.08 \pm 0.29$ & $20.39 \pm 0.71^{\mathrm{d}}$ & $22.81 \pm 0.50^{c}$ & $28.67 \pm 0.51$ & $34.581 \pm 0.66$ \\
\hline 2017 & 155 & $3.47 \pm 0.05$ & $12.75 \pm 0.26$ & $18.34 \pm 0.64^{c}$ & $20.53 \pm 0.51^{b}$ & $25.01 \pm 0.52$ & $30.944 \pm 1.09$ \\
\hline Age of dam & & $(p=0.211)^{\mathrm{NS}}$ & $(\mathrm{p}=0.32)^{\mathrm{NS}}$ & $(\mathrm{p}=0.02)^{\mathrm{NS}}$ & $(\mathrm{p}=0.632)^{\mathrm{NS}}$ & $(\mathrm{p}=0.02)^{\mathrm{NS}}$ & $(p=0.790)^{N S}$ \\
\hline$<36$ Months & 89 & $3.24 \pm 0.07^{b}$ & $11.16 \pm 0.33$ & $16.33 \pm 1.05$ & $19.42 \pm 0.59^{\mathrm{a}}$ & $24.01 \pm 0.63^{\mathrm{a}}$ & $32.02 \pm 0.96$ \\
\hline $36-48$ & 168 & $3.29 \pm 0.05^{\mathrm{a}}$ & $11.42 \pm 0.25$ & $17.58 \pm 0.88$ & $19.67 \pm 0.47^{\mathrm{a}}$ & $23.54 \pm 0.56^{\mathrm{a}}$ & $31.74 \pm 0.89$ \\
\hline $48-60$ & 145 & $3.28 \pm 0.06^{\mathrm{a}}$ & $11.36 \pm 0.29$ & $16.85 \pm 1.07$ & $19.04 \pm 0.61^{\mathrm{a}}$ & $23.58 \pm 0.65^{\mathrm{a}}$ & $32.05 \pm 0.93$ \\
\hline $60-72$ & 83 & $3.24 \pm 0.07^{\mathrm{ab}}$ & $11.72 \pm 0.34$ & $17.42 \pm 1.16$ & $19.93 \pm 0.61^{\mathrm{a}}$ & $27.03 \pm 0.61^{b}$ & $34.23 \pm 0.98$ \\
\hline$>72$ & 342 & $3.30 \pm 0.04^{b}$ & $11.25 \pm 0.21$ & $15.72 \pm 0.88$ & $19.60 \pm 0.40^{\mathrm{a}}$ & $23.25 \pm 0.69^{\mathrm{a}}$ & $32.84 \pm 0.74$ \\
\hline Sex & & $(\mathrm{p}=0.021)^{*}$ & $(\mathrm{p}=0.081)^{\mathrm{NS}}$ & $(\mathrm{p}=0.219)^{\mathrm{NS}}$ & $(\mathrm{p}=0.868)^{\mathrm{NS}}$ & $(\mathrm{p}=0.001)^{* *}$ & $(\mathrm{p}=0.540)^{\mathrm{NS}}$ \\
\hline Male & 407 & $3.34 \pm 0.04^{\mathrm{a}}$ & $11.59 \pm 0.19^{\mathrm{a}}$ & $16.88 \pm 0.67$ & $19.62 \pm 0.35$ & $26.10 \pm 0.39$ & $33.14 \pm 0.57$ \\
\hline \multirow[t]{3}{*}{ Female } & 420 & $3.21 \pm 0.04^{\mathrm{b}}$ & $11.17 \pm 0.18^{b}$ & $16.75 \pm 0.59$ & $19.46 \pm 0.32$ & $22.10 \pm 0.28$ & $31.84 \pm 0.57$ \\
\hline & & \multicolumn{6}{|c|}{ Wool Traits } \\
\hline & & AGW (Kg) & FD $(\mu)$ & SL $(\mathbf{c m})$ & CPC & $\operatorname{ML}(\%)$ & $\mathbf{L S}$ \\
\hline Overall & 827 & $1.75 \pm 0.03$ & $20.99 \pm 0.08$ & $3.43 \pm 0.10$ & $4.87 \pm 0.20$ & $3.26 \pm 0.37$ & $1.20 \pm 0.22$ \\
\hline Fec-intr & & $(\mathrm{p}=0.001)^{* *}$ & $(p=0.021)^{*}$ & $(\mathrm{p}=0.063)^{\mathrm{NS}}$ & $(\mathrm{p}=0.001)^{* *}$ & $(0.001)^{* *}$ & $(\mathrm{p}=0.001)^{* *}$ \\
\hline PKM & 625 & $1.77 \pm 0.03$ & 20.880 .07 & $3.47 \pm 0.10$ & $5.08 \pm 0.32$ & Nil & $1.08 \pm 0.03$ \\
\hline Fec-b KM & 202 & $1.12 \pm 0.04$ & $21.10 \pm 0.13$ & $3.39 \pm 0.19$ & $4.66 \pm 0.36$ & $3.26 \pm 0.37$ & $1.40 \pm 0.04$ \\
\hline year & & $(\mathrm{p}=0.0001)^{* *}$ & $(\mathrm{p}=0.0001)^{* *}$ & $(\mathrm{p}=0.0001)^{* *}$ & $(\mathrm{p}=0.0001)^{* *}$ & $(\mathrm{p}=0.0001)^{* *}$ & $(\mathrm{p}=0.001)^{* *}$ \\
\hline 2014 & 263 & $1.47 \pm 0.06^{\mathrm{a}}$ & $21.10 \pm 0.15^{b}$ & $3.72 \pm 0.22^{\mathrm{a}}$ & $5.35 \pm 0.15^{b}$ & $3.13 \pm 0.63$ & $1.07 \pm 0.04$ \\
\hline 2015 & 284 & $1.58 \pm 0.05^{\mathrm{a}}$ & $20.51 \pm 0.15^{\mathrm{a}}$ & $2.48 \pm 0.22^{\mathrm{b}}$ & $5.89 \pm 0.15^{b}$ & $3.62 \pm 0.54$ & $1.23 \pm 0.04$ \\
\hline 2016 & 125 & $2.21 \pm 0.08^{b}$ & $20.50 \pm 0.19^{\mathrm{a}}$ & $3.83 \pm 0.28^{\mathrm{a}}$ & $5.32 \pm 0.17^{b}$ & $3.25 \pm 1.08$ & $1.09 \pm 0.05$ \\
\hline 2017 & 155 & $1.76 \pm 0.13^{c}$ & $21.50 \pm 0.39^{b}$ & $3.72 \pm 0.06^{\mathrm{a}}$ & $2.92 \pm 0.16^{\mathrm{a}}$ & $2.90 \pm 0.94^{\mathrm{a}}$ & $1.50 \pm 0.05$ \\
\hline Age of dam & & $(\mathrm{p}=0.210)^{\mathrm{NS}}$ & $(\mathrm{p}=0.0001)^{* *}$ & $(\mathrm{p}=0.02)^{\mathrm{NS}}$ & $\mathrm{p}=(0.056)^{\mathrm{NS}}$ & $(\mathrm{p}=0.0001)^{* *}$ & $(\mathrm{p}=0.863)^{\mathrm{NS}}$ \\
\hline$<36$ Months & 89 & $1.65 \pm 0.05^{\mathrm{a}}$ & $20.92 \pm 0.12^{\mathrm{a}}$ & $3.44 \pm 0.17$ & $4.96 \pm 0.12$ & $3.30 \pm 0.88$ & $1.21 \pm 0.05$ \\
\hline $36-48$ & 168 & $1.79 \pm 0.04^{\mathrm{a}}$ & $21.10 \pm 0.10^{\mathrm{b}}$ & $3.59 \pm 0.15^{\mathrm{b}}$ & 4.9200 .04 & $2.77 \pm 0.73$ & $1.24 \pm 0.04$ \\
\hline $48-60$ & 145 & $1.77 \pm 0.04^{\mathrm{a}}$ & $20.92 \pm 0.12^{\mathrm{a}}$ & $3.41 \pm 0.18^{\mathrm{b}}$ & $4.88 \pm 0.34$ & $4.08 \pm 0.0 .94$ & $1.18 \pm 0.06$ \\
\hline $60-72$ & 83 & $1.78 \pm 0.05^{\mathrm{a}}$ & $21.02 \pm 0.12$ & $3.50 \pm 0.19^{b}$ & $4.72 \pm 0.16$ & $3.82 \pm 0.95$ & $1.23 \pm 0.06$ \\
\hline$>72$ & 342 & $1.17 \pm 0.04^{\mathrm{a}}$ & $21.02 \pm 0.09$ & $3.19 \pm 0.13^{\mathrm{b}}$ & $4.86 \pm 0.30$ & $3.33 \pm 0.0 .50$ & 1.170 .04 \\
\hline Sex & & $(\mathrm{p}=0.211)^{\mathrm{NS}}$ & $(\mathrm{p}=0.0001)^{* *}$ & $(\mathrm{p}=0.0201)^{*}$ & $(\mathrm{p}=0.064)^{\mathrm{NS}}$ & $(0.230)^{\mathrm{NS}}$ & $(\mathrm{p}=0.829)^{\mathrm{NS}}$ \\
\hline Male & 407 & $1.77 \pm 0.03^{\mathrm{a}}$ & $20.90 \pm 0.08$ & $3.35 \pm 0.12$ & $4.96 \pm 0.22$ & $3.57 \pm 0.49$ & $1.08 \pm 0.03$ \\
\hline Female & 420 & $1.72 \pm 0.03$ & $21.08 \pm 0.08$ & $3.50 \pm 0.11$ & $4.78 \pm 0.23$ & $2.92 \pm 0.55$ & $1.20 \pm 0.04$ \\
\hline
\end{tabular}

NS indicates non-significant

$*$ indicates significant at $5 \%$ level

***Indicates significant at $1 \%$ level

Significant effects of age of dam at lambing, on body weight at different ages, have been observed by some workers in Corriedale and its crosses with other breeds of sheep. Bhadula and Bhat (1980) have reported significant effect of age of dam on BW, WW, W6, 9-MWT, 12-MWT; Garcia et al., (1985) on BW, WW; Ahn et al., (1990) on BW, WW. However non-significant influence of age of dam at lambing has also been reported on birth and WW by Negi et al., (1987) in Gaddi and its crosses.

The birth weight and wool traits of Kashmir Merino sheep introgressed with Fec-B gene were significantly lower than purebred Kashmir Merino sheep. The wool traits in terms of yield and fineness were significantly affected. However, these traits can be improved by backcrossing with superior 
Kashmir Merino sires. The litter size was improved by Fec-B introgression.

\section{Acknowledgements}

Authors are thankful to the Director Sheep Husbandry Department for providing necessary facilities and help for the present investigation.

\section{References}

Ahn, B. S., Suh, K. H., Oh, D. K. and Kim, N. S. (1990). Effect of genetic and environmental factors on birth and weaning weight and greasy fleece weight in sheep. Korean Journal of Animal Sciences 32(4): 202-204.

Anonymous. 2018. Directorate of Sheep Husbandry Kashmir division, Government of Jammu and Kashmir.

Ashraf, B.A. 2016. Genetic evaluation and trends of growth and age at first lambing in Corriedale flock of sheep in Kashmir. M.V.Sc. thesis. Sher-eKashmir University of Agricultural Sciences \& Technology of Kashmir. Thesis submitted to Division of Animal Genetics and Breeding.

Bhadula, S.K. and Bhat P. N. (1980). Genetic and phenotypic parameters of body weight in Muzaffarnagri sheep and their Corriedale half breds. Indian Journal of Animal Sciences 50: 1094-97.

Chu, M.X., Liu, Z.H., Jiao, C.L., He, Y.Q., Fang, L., Ye, S.C., Chen, G.H. and Wang, J.Y., 2007. Mutations in BMPRIB and BMP-15 genes are associated with litter size in Small Tailed Han sheep (Ovis aries). Journal of Animal Science, 85(3): 598-603.

Das, A.K., Chakraborty, D., Kumar, N., Gupta, P., Khan, N.N. and Bukhari, S. 2014. Effects of non-genetic factors on performance traits of Kashmir Merino sheep. Indian Journal of Animal
Research. 48(2): 106-108.

Dey, B. 2004. Genetic studies on reproduction and production traits of Nali sheep. M.V.Sc. thesis, CCS Haryana Agricultural University, Hisar, Haryana, India.

Dixit, S.P., Singh, G., Kant, N. and Dhillon, J.S. 2009. Contribution of genetic and phenotypic parameters affecting fleece traits in 3/4th bred Bharat Merino Sheep. Indian Journal of Animal Research. 43(1): 1-6.

Garcia F.X., Neira, R.R. and Vega, M. (1985). Non genetic effects on body weight in Corriedale sheep. Avancas en Production Animal 10(1-2):89-100

Harvey, W.R. 1990. User's Guide for LSMLMW and MIXMDL PC-2 version. Mixed model least-squares and maximum likelihood computer program, Ohio State University, Columbus, Ohio, USA.

Kannojia, K., Yadav, S.B.S., Narula, H.K., Pannu, U. and Singh, H. 2016. Genetic parameters of body weights in Marwari sheep. Indian Journal of Small Ruminants 22: 222-224.

Kramer, C.R. 1957. Extension of multiple range tests to group correlated means. Biometrics, 13: 13-18.

Kumar, S., Mishra, A.K., Kolte, A.P., Arora, A.L., Singh, D. and Singh, V.K., 2008. Effects of the Booroola (FecB) genotypes on growth performance, ewe's productivity efficiency and litter size in Garolex Malpura sheep. Animal reproduction science, 105(3-4). 319. 331.

Lalit, Z.S., Malik, Z.S., Dalal, D.S., Patil, C.S. and Dahiya, S.P. 2017. Genetic studies on growth, reproduction and wool production traits in Harnali sheep. Indian Journal of Animal Research. 51(5):813-816.

Mahajan, V., Das, A.K., Taggar, R.K., Kumar, D., Khan, N., Sharma, R. and 
Shanti, V.R. 2018. Non-Genetic Factors Influencing the Wool Traits of Rambouillet Sheep in Jammu. International Journal of Current Microbiology and Applied Sciences. 7: 3966-3973

Meyer, H.H., Bigham, M.L., Baker, R.L., Harvey, T.G. and Hickey, S.M., 1994. Effects of Booroola Merino breeding and the FecB gene on performance of crosses with longwool breeds. 1. Effects on growth, onset of puberty, wool production and wool traits. Livestock Production Science, 39(2), pp.183-190.

Negi, P.R., Bhat, P.P. and Garg, R.C. (1987). Factors affecting preweaning body weight in Gaddi and its crosses. Indian journal of Animal Sciences 57:489-492

Nimbkar, C., Ghalsasi, P.M., Nimbkar, B.V., Walkden-Brown, S.W., Maddox, J.F., Gupta, V.S., Pardeshi, V.C., Ghalsasi, P., van der Werf, J.H.J., 2007. Reproductive performance of Indian crossbred Deccani ewes carrying the FecB mutation. Proc. Assoc. Advmnt. Anim. Breed. Genet. 17, 430-433.

Ponzoni, R.W., Fleet, M.R., Walkley, J.R.W. and Walker, S.K., 1985. A note on the effect of the $\mathrm{F}$ gene on wool production and live weight of Booroolax South Australian Merino rams. Animal Science, 40(2), 367-369.

Ponzoni, R.W., Walker, S.K., Walkley, J.R.W., Fleet, M.R., 1985b. The productivity of Bungaree, Booroola×Bungaree and Trangie
Fertility $\times$ Bungaree Merino ewes in South Australia. In: Land, R.B., Robinson, D.W. (Eds.), Genetics of Reproduction in Sheep. Butterworths, London, UK. 127-137.

Tohidi, R., Ismailjami, Y. and Javanmard, A. 2017. Analysis of the Environmental Factors Affecting the Growth Traits of Iran-Black Sheep. International Journal of Environment, Agriculture and Biotechnology.2 (1): 2456-1878.

Vivekanand, Joshi R K, Narula H K, Singh H and Chopra A. 2014a. Effect of genetic and non-genetic factors on growth of Magra sheep in arid region of Rajasthan. Indian Journal of Small Ruminants 20 (2): 19-22.

Walkden-Brown, S.W., Wolfenden, D.H., Charles, R.J. and Maddox, J.F., 2007. Expression of reproductive and production traits in commercial Merino ewes having 0,1 or 2 copies of the FecB mutation. In Proceedings of the Association for the Advancement of Animal Breeding and Genetics 17, 426429.

Yadav, U., Dalal, D. S., Dahiya, S. P. Patil, C. S. (2018). Estimation of Genetic Parameters for Reproduction Traits in Munjal Sheep, International Journal of Livestock Research. 8(1): 195-201.

Zaffer, V., Taggar, R.K. and Chakraborty, D. 2015. Non-genetic factors affecting growth and production traits in Dorper crossbred sheep. Journal of Animal Research. 5 (2): 227.

\section{How to cite this article:}

Mubashir Ali Rather, Suhail Magray, Showkat Ahamad Ahanger, Mohmmad Ashraf Baba, M. Maroof Shah, Tenveer Ahmad Rather, Younis Farooq and Qayim Abbas. 2019. Effect of Some Non-genetic Factors and Fec-B Gene Introgression on Performance Traits of Kashmir Merino Sheep. Int.J.Curr.Microbiol.App.Sci. 8(08): 444-449. doi: https://doi.org/10.20546/ijcmas.2019.808.050 